\title{
Analisis Pengaruh Sudut Penyalaan TRIAC Terhadap Pengaturan Kecepatan Motor Induksi Satu Fasa Menggunakan Cycloconverter
}

\author{
Muhammad Alvin Saputra ${ }^{1}$, Afriyastuti Herawati ${ }^{1}$, Ika Novia Anggraini ${ }^{1}$ \\ ${ }^{1}$ Program Studi Teknik Elektro Universitas Bengkulu \\ afriyastuti_herawati@unib.ac.id
}

\begin{abstract}
A single-phase induction motor is one type of electric motor that is most widely used in everyday's life, especially for running small loads. The application of this single phase induction motor is not only in households but also in shops, shopping centers, and industry. In its operation, single-phase induction motors can be operated with constant speed and variable speed. The operation of a single-phase induction motor at a constant speed can be done by inputting the nominal voltage and frequency of the motor. Meanwhile, the operation of a single-phase induction motor with varying speeds can be done by adjusting the input frequency of the motor. In this study, an induction motor speed control was carried out using a cycloconverter to regulate the speed of a single-phase induction motor by changing the input frequency of the motor into three variations, namely $\mathrm{f} / 1, \mathrm{f} / 2$ and $\mathrm{f} / 3$ at the base frequency of $50 \mathrm{~Hz}$. The cycloconverter switching was designed using TRIAC and then a study was carried out on the effect of the TRIAC's firing angle on the speed, voltage and output power of the motor by varying firing angles by $0^{\circ}, 30^{\circ}, 45^{\circ}, 60^{\circ}$ and $90^{\circ}$. The result show, it is found that increasing the firing angle, the motor output voltage decrease, the motor output power also decrease, except at the angle of $60^{\circ}$ rises then at the angle of 90 decrease again, while the motor speed increases at the same frequency.
\end{abstract}

\section{Keyword: cycloconverter, firing angle, TRIAC.}

\section{PENDAHULUAN}

Motor induksi satu fasa merupakan motor yang sederhana, kuat dan handal, dan digunakan dalam jumlah yang besar pada rumah tangga, toko-toko, kantor-kantor dan perusahaan-perusahaan ketika suplai tiga fasa tidak tersedia. Walaupun memungkinkan untuk menghasilkan daya sampai beberapa kilowatt $(\mathrm{kW})$, tetapi sebagian besar motor induksi satu fasa yang tersedia dalam kapasitas daya di bawah 0.5 kiloWatt $(\mathrm{kW})$, dan digunakan pada berbagai peralatan seperti kompressor pada lemari es, mesin cuci, kipas angin, blender, mesin print dan lain-lain.

Dalam operasi kerjanya, motor induksi satu fasa dapat beroperasi pada suatu nilai kecepatan tertentu (konstan) dan pada kecepatan yang dapat diatur sesuai dengan referensi kecepatan yang diinginkan. Namun umumnya motor induksi yang ada pada saat ini tidak diatur kecepatan putarannya, artinya kecepatan motor induksi tersebut berputar secara diskrit yaitu berputar pada suatu kecepatan tertentu (konstan).

Untuk mendapatkan kecepatan putaran motor induksi satu fasa yang bervariasi dapat dilakukan menggunakan dua peralatan yaitu inverter dan cycloconverter [1][2]. Pada penelitian ini akan digunakan cycloconverter dalam memvariasikan kecepatan motor.

Penelitian mengenai pengaturan motor induksi satu fasa menggunakan cycloconverter sudah pernah dilakukan. Diantaranya menggunakan pensaklaran thyristor dan TRIAC [3][4][5]. Namun kebanyakan penelitian tersebut hanya berfokus pada hubungan antara frekuensi dengan kecepatan. Sedangkan untuk pengaruh sudut penyalaan terhadap kecepatan motor jarang dibahas. Sedangkan pengaturan frekuensi pada cycloconverter berbasis TRIAC dilakukan dengan cara pengaturan sudut penyalaannya sehingga sangat penting untuk menganalisis hubungan antara sudut penyalaan terhadap besaran-besaran pada motor induksi satu fasa. Pada penelitian ini akan dilakukan analisis pengaruh sudut penyalaan TRIAC terhadap besaran-besaran pada motor induksi satu fasa yaitu tegangan, daya keluaran motor dan kecepatan motor.

\section{TINJAUAN PUSTAKA}

\section{Cycloconverter}

Cycloconverter merupakan suatu alat yang dapat mengubah daya bolak balik secara langsung dari satu frekuensi masukan menjadi daya keluaran bolak balik pada frekuensi yang berbeda (biasanya lebih kecil dari masukkannya)[1]. Cycloconverter terdiri dari beberapa switch (triac, thyristor, ataupun Silicon Control Rectifier) yang disusun pararel dengan sumber. Besar tegangan maupun frekuensi keluaran dapat divariasikan dengan mengatur pensaklaran konverter. Rangkaian cycloconverter dapat dilihat pada Gambar 2.3.

Pada Gambar 1.a. dapat dilihat rangkaian daya cycloconverter satu phasa. Untuk lebih mudah memahami kerja rangkaian ini sehingga dapat menurunkan frekuensi sumber adalah dengan cara membagi topologi ini menjadi 2 buah rangkaian konverter thyristor-P dan rangkaian konverter thyristor$\mathrm{N}$ yang bekerja secara bergantian, seperti terlihat pada Gambar 1.b. Konverter thyristor-P bekerja untuk membentuk tegangan keluaran pada saat periode positifnya, sedangkan konverter thyristor-N bekerja 
setelahnya untuk membentuk tegangan keluaran pada periode negatif arus keluaran.

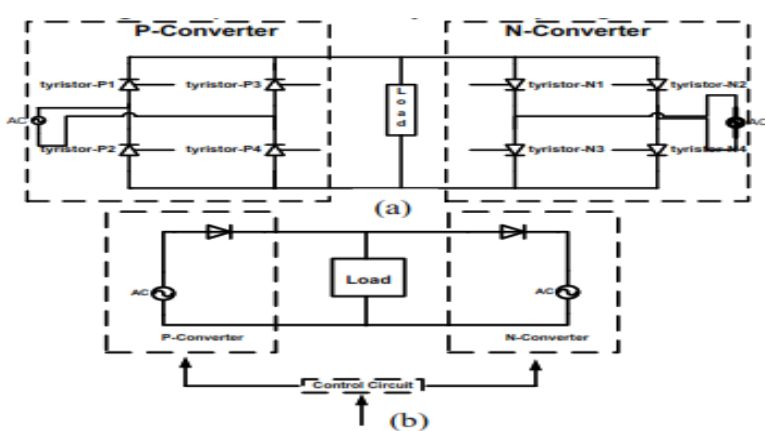

Gambar 1. (a) Rangkaian Cycloconverter Satu Fasa dan (b) Rangkaian Ekivalen [4]

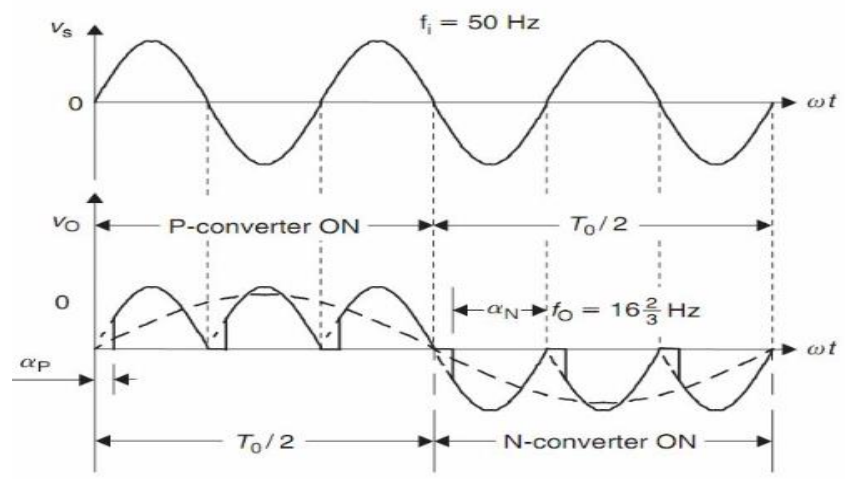

Gambar 2. Gelombang Masukan dan Keluaran Cycloconverter dari $50 \mathrm{~Hz}$ ke 16,7 Hz dengan Beban Resistif [4]

Pada Gambar 2 terlihat bahwa untuk mengubah sumber tegangan AC $50 \mathrm{~Hz}$ menjadi frekuensi yang lebih rendah $(16,67 \mathrm{~Hz})$, rangkaian konverter thyristor lengan kiri bekerja sedemikian rupa dengan memainkan sudut penyalaannya selama 1,5 periode sumber. Konverter thyristor lengan kanan bekerja setelahnya [4].

\section{Motor Induksi Satu Fasa}

Motor induksi satu fasa secara relatif memiliki konstruksi yang sederhana. Motor jenis induksi memiliki rotor sangkar dan kumparan stator terdistribusi satu fasa. Sebagaimana sifat motor satu fasa yang terdiri atas medan maju dan medan mundur sehingga resultan medannya menjadi nol dan tidak akan start untuk berputar jika kumparan stator dihubungkan ke sebuah suplai ac. Tetapi, jika rotor diberikan sebuah putaran atau distart dengan peralatan tambahan,motor akan kontinyu berputar.

Motor induksi satu fasa mulai bergerak lebih cepat ketika stator dari motor induksi satu fasa tersebut dihubungkan ke suplai daya, arus stator menghasilkan sebuah gaya magnetomotif yang ekivalen terhadap dua gelombang magnetomotif dengan amplitude konstan yang berputar dalam arah berlawanan pada kecepatan sinkron. Masing-masing dari gelombang berputar ini menginduksikan arus pada rangkaian rotor dan menghasilkan aksi motor induksi yang sama seperti pada mesin induksi fasa banyak. Teori medan berputar ganda dapat digunakan dalam analisis untuk menentukan performansi kualitatif dan kuantitatif motor induksi satu fasa.

Pertama kita anggap rotor dalam keadaan diam dan kumparan stator dieksitasi dari sebuah suplai satu fasa. Ini ekivalen dengan sebuah trafo yang sisi sekundernya dihubung singkat. Rangkaian ekivalennya seperti pada gambar 3 .

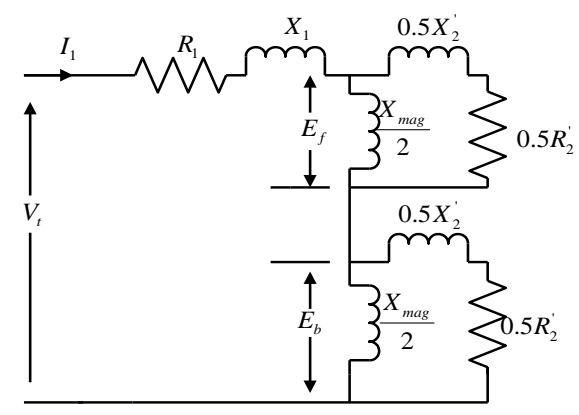

(a)

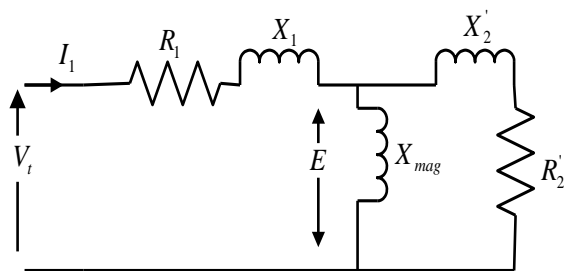

(b)

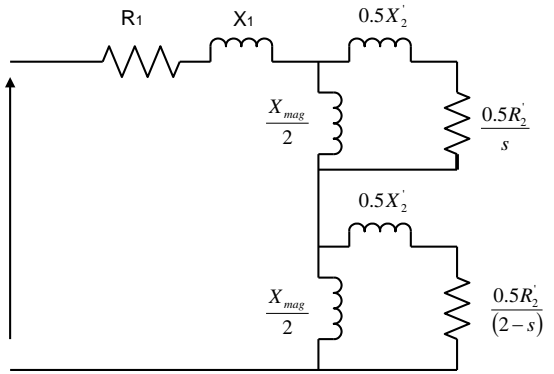

(c)

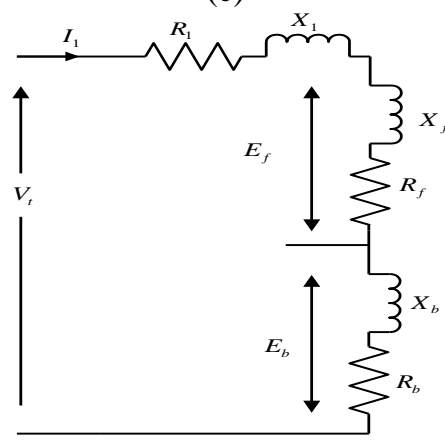

(d)

Gambar 3. Rangkaian Ekivalen motor induksi satu fasa (a) dan (b) rotor pada keadaan diam. (c) dan (d) rotor berputar pada slip s.[1]

Dimana

$\mathrm{R} 1=$ resistansi kumparan stator

$X_{1}=$ reaktansi bocor kumparan stator

$X_{\text {mag }}=$ reaktansi magnetisasi 
$X_{2}^{\prime}=$ reaktansi bocor rotor terhadap stator

$R_{2}^{\prime} \quad=$ resistansi rotor terhadap stator

$V_{t} \quad=$ tegangan suplai

$E \quad=$ tegangan induksi pada kumparan stator (atau tegangan celah udara)

Dan[1]:

$$
E=4.44 f N \phi
$$

Dimana $\phi$ adalah fluks celah udara.

Berdasarkan teori medan berputar ganda, rangkaian ekivalen dapat dipecah menjadi dua bagian seperti yang ditunjukkan pada gambar diatas, representasi dampak dari medan maju dan medan mundur.[1]

$$
\begin{aligned}
& E_{f}=4.44 f N \phi_{f} \\
& E_{b}=4.44 f N \phi_{b}
\end{aligned}
$$

Pada keadaan diam, dimana $\phi_{f}=\phi_{b}$, maka $E_{f}=E_{b}$

Sekarang anggap motor dalam keadaan berputar pada kecepatan tertentu dalam arah medan berputar maju, slip menjadi s. arus rotor terinduksi oleh medan maju dengan frekuensi sf, dimana f merupakan frekuensi stator. Sebagaimana pada motor banyak fasa, gaya magnetomotive rotor berputar pada slip rpm dengan respek pada stator. Hasil dari gaya magnetomotiv stator dan gaya magnetomotif rotor maju menghasilkan sebuah fluks celah udara maju yang menginduksikan tegangan Ef. Rangkaian rotor dicerminkan terhadap stator memiliki impedansi $j 0.5 X_{2}^{\prime}+\frac{0.5 R_{2}^{\prime}}{s}$ seperti yang ditunjukkan pada gambar 2.2c diatas.

Sekarang perhatikan medan berputar mundur (backward), yang menginduksikan arus ke rangkaian rotor pada frekuensi slip (2-s)f. Gaya magnetomotif rotor berputar di celah udara pada kecepatan sinkron dalam arah mundur ( backward ). Jumlah dari gaya magnetomotif stator mundur dan gaya magnetomotif rotor menghasilkan sebuah fluks celah udara mundur yang menginduksikan tegangan $E_{b}$. Rangkaian rotor yang tercerminkan memiliki impedansi $j 0.5 X_{2}^{\prime}+\frac{0.5 R_{2}^{\prime}}{(2-s)} \quad$ seperti yang ditunjukkan pada gambar 2.2c. Pada slip yang kecil, bentuk gelombang arus rotor akan menunjukkan komponen frekuensi tinggi [pada $(2-s) f \approx 2 f$ ] mengikuti medan mundur, sedangkan pada komponen frekuensi rendah ( pada $s f$ ) mengikuti medan maju.[1]

Hal ini jelas dari rengkaian ekivalen yang pada kondisi motor berputar (running), $Z_{f}>Z_{b}, E_{f}>E_{b}$ ., dan sebab itu fluks celah udara maju $\phi_{f}$ akan lebih besar daripada fluks celah udara mundur $\phi_{b}$. Parameterparameter dari rangkaian pada gambar c dapat ditentukan dengan dua tes performansi pada motor induksi satu fasa.
Rangkaian ekivalen dapat digunakan untuk menentukan performansi dari motor dengan penghitungan arus stator, daya masukan, torka yang dikembangkan, efisiensi dan seterusnya untuk suatu kecepatan tertentu. Untuk menyederhanakan penghitungan, rangkaian ekivalen sederhana dari gambar d dapat digunakan,[1]

$$
\begin{gathered}
Z_{f}=R_{f}+j X_{f}=\frac{j 0.5 X_{m a g}\left(j 0.5 X_{2}^{\prime}+\frac{0.5 R_{2}^{\prime}}{s}\right)}{\frac{0.5 R_{2}^{\prime}}{s}+j 0.5\left(X_{\text {mag }}+X_{2}^{\prime}\right)} \ldots \cdots \\
Z_{b}=R_{b}+j X_{b}=\frac{j 0.5 X_{m a g}\left(j 0.5 X_{2}^{\prime}+\frac{0.5 R_{2}^{\prime}}{(2-s)}\right)}{\frac{0.5 R_{2}^{\prime}}{(2-s)}+j 0.5\left(X_{\text {mag }}+X_{2}^{\prime}\right)}
\end{gathered}
$$

Daya celah udara terhadap medan maju dan medan mundur yaitu [1] :

$$
\begin{aligned}
& P_{g f}=I_{1}^{2} R_{f} \\
& P_{g b}=I_{1}^{2} R_{b}
\end{aligned}
$$

Dan torkanya [1] :

$$
\begin{gathered}
T_{f}=\frac{P_{g f}}{\omega_{\text {sin }}} \\
T_{b}=\frac{P_{g b}}{\omega_{\sin }}
\end{gathered}
$$

jumlah torkanya adalah[1] :

$$
T=T_{f}-T_{b}=\left(\frac{I_{1}^{2}}{\omega_{\text {sin }}}\right)\left(R_{f}-R_{b}\right)
$$

Daya mekanik yang dikembangkan yaitu[1] :

$$
\begin{aligned}
P_{m e k} & =T \omega_{m} \ldots \ldots \ldots \ldots \ldots \ldots \ldots \\
& =T \omega_{\text {sin }}(1-s) \ldots \ldots \ldots \ldots \\
& =I_{1}^{2}\left(R_{f}-R_{b}\right)(1-s) \ldots \\
& =\left(P_{g f}-P_{g b}\right)(1-s) \ldots
\end{aligned}
$$

daya keluarannya [1]:

$$
P_{\text {out }}=P_{\text {mek }}-P_{\text {rot }}
$$

Dimana Prot termasuk rugi-rugi angin dan gesekan, dan ini diasumsikan rugi-rugi inti besi juga termasuk dalam rugi-rugi rotasi. Dua medan celah udara menghasilkan arus pada rangkaian rotor pada frekuensi yang berbeda. Oleh karena itu rugi-rugi tembaga rotor ( rugi-rugi $\mathrm{I}^{2} \mathrm{R}$ ) merupakan jumlah numerik dari rugi-rugi yang dihasilkan pada masing-masing medan.

Rugi-rugi tembaga rotor yang dihasilkan oleh medan maju adalah [1]:

$$
P_{2 f}=s P_{g}
$$

Dan yang dihasilkan oleh medan mundur adalah [1]: 


$$
P_{2 b}=(2-s) P_{g b}
$$

Total rugi-rugi tembaga rotor adalah [1] :

$$
P_{2}=s P_{g f}+(2-s) P_{g b}
$$

Total daya celah udara merupakan jumlah numerik dari daya celah udara yang diserap dari stator oleh dua komponen medan celah udara, yaitu [1] :

$$
P_{g}=P_{g f}+P_{g b}
$$

\section{METODE PENELITIAN}

\subsection{Objek Penelitian}

Pada penelitian yang dilakukan menggunakan objek yaitu motor induksi satu fasa dengan spesifikasi yang tertera pada Tabel 1.

Tabel 1 Spesifikasi motor induksi satu fasa

\begin{tabular}{ccc}
\hline No. & Parameter & Nilai \\
\hline 1. & Tegangan Nominal & $220 \mathrm{~V}$ \\
2. & Kecepatan (Ns) & $3000 \mathrm{Rpm}$ \\
3. & Daya & $1 / 4 \mathrm{HP}$ \\
4. & Arus & $<1,9 \mathrm{~A}$ \\
5. & Frekuensi & $50 \mathrm{~Hz}$ \\
6. & Jumlah Kutub & 2 \\
\hline
\end{tabular}

\subsection{Diagram Blok Keseluruhan Sistem}

Penelitian ini dilakukan dengan dua bagian yaitu perancangan perangkat keras (hardware) dan tahap perancangan perangkat lunak (software). Pada bagian ini menjelaskan perancangan secara umum dari sistem kerja pengaturan kecepatan putaran motor induksi satu fasa. Perancangan meliputi diagram blok sistem yang diinginkan, sehingga setiap komponen yang membangun sistem kerja ini bisa tergambar dengan jelas. Keseluruhan sistem dari perancangan alat ini ditunjukkan dalam diagram blok pada Gambar 3.1 diagram blok keseluruhan sistem.

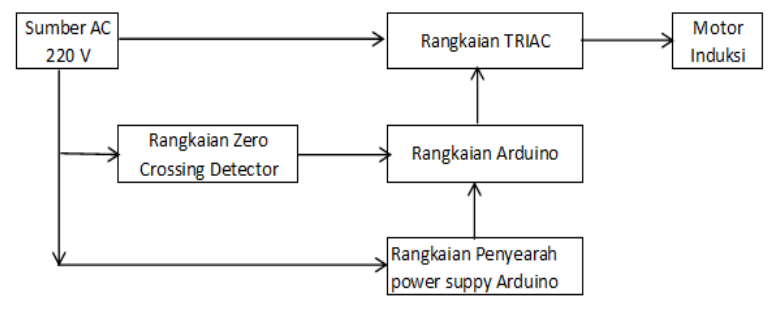

Gambar 4. Diagram Blok Keseluruhan Sistem

Pada Gambar 4 Diagram blok keseluruhan sistem terlihat bahwa sumber tegangan yang digunakan adalah sumber tegangan listrik AC 220 Volt $50 \mathrm{~Hz}$. Dari sumber tegangan listrik AC $220 \mathrm{~V}$ ini dibutuhkan untuk rangkaian zero crossing detector dan perancangan catu daya. Rangkaian zero crossing detector digunakan untuk mendapatkan titik persimpangan antara gelombang tegangan bolak-balik dengan titik nol. Selanjutnya, sinyal keluaran rangkaian zero crossing detector ini akan diolah arduino. Kemudian, rangkaian power supply digunakan sebagai sumber tegangan untuk rangkaian arduino. Pada rangkaian arduino ini digunakan untuk mengatur sinyal switching dari kontrol yang dipengaruhi oleh zero crossing detector. Pada rangkaian cycloconverter, frekuensi output satu fasa kemudian diturunkan tergantung nilai dari switching yang diberikan. Frekuensi output satu fasa divariasikan yaitu frekuensi input, 1/2 frekuensi input, dan $1 / 3$ frekuensi input. Ketika arduino diset $1 / 2$ frekuensi input maka arduino akan mengeluarkan sinyal switching sehingga frekuensi output yang dihasilkan setengah dari frekuensi input yang diberikan (Gambar 5).

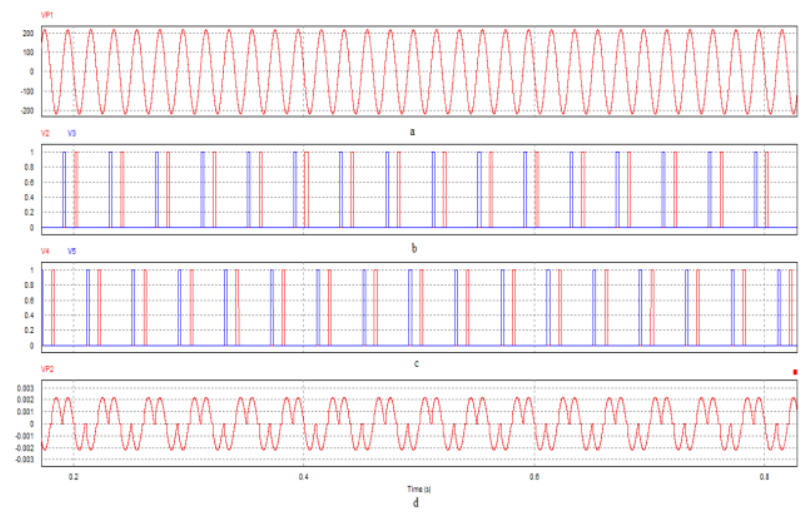

Gambar 5. Prinsip kerja cycloconverter (a) Sinyal input cycloconverter (b) Sinyal trigger untuk gate A dan D (c)

Sinyal trigger untuk gate C dan B (d) Sinyal output cycloconverter

\subsection{Pegujian}

Pengujian pada penelitian ini akan dilakukan dengan memvariasikan sudut penyalaan TRIAC, dimulai dari $0^{\circ}, 30^{\circ}$, $45^{\circ}, 60^{\circ}$, sampai $90^{\circ}$. Kemudian pada setiap nilai sudut penyalaan akan divariasikan frekuensinya mulai dari $f / 1, f / 2$ sampai $\mathrm{f} / 3$ dengan $\mathrm{f}$ adalah frekuensi dasar PLN sebesar $50 \mathrm{~Hz}$. Setelah itu diukur besaran-besarannya yaitu tegangan, arus, daya dan kecepatan motor. Hasilnya kemudian dianalisis.

\section{HASIL DAN PEMBAHASAN}

\subsection{Pengujian Kecepatan Rotor Motor Induksi Tanpa Kendali}

Pada pengujian ini merupakan tahapan awal dari sistem kendali motor induksi satu fasa. Pengujian dilakukan untuk mengetahui kecepatan putaran yang dihasilkan pada motor yang digunakan tanpa kendali. Adapun karakteristik motor induksi satu fasa tertera pada Tabel 1 memiliki kecepatan putaran sinkron motor sebesar $3000 \mathrm{rpm}$ dan frekuensi $50 \mathrm{~Hz}$. Kecepatan putaran motor diukur menggunakan tachometer dan nilai yang didapat memiliki selisih yang lebih rendah dari kecepatan putaran sinkronnya. Hal ini dikarenakan tegangan induksi hanya akan terbangkitkan jika terjadi slip yaitu perbedaan kecepatan rotor dan kecepatan medan putara stator yang mengakibatkan perpotongan 
antara medan putaran stator dengan konduktor rotor, sehingga motor induksi dapat berputar.

Nilai kecepatan medan stator yang didapat berdasarkan persamaan 2.1 yaitu $3000 \mathrm{rpm}$ dengan frekuensi $50 \mathrm{~Hz}$, sesuai dengan kecepatan nominal motor.

$$
\mathrm{n}_{\mathrm{s}}=\frac{120 \times 50 \mathrm{~Hz}}{2}=3000 \mathrm{rpm}
$$

Setelah didapatkan nilai kecepatan medan stator maka dapat dilakukan perhitungan nilai slip yang terjadi pada motor induksi menggunakan persamaan 2.2.

$$
\text { Slip }=\frac{3000 \times 2951}{3000} \times 100 \%=1,63 \%
$$

\subsection{Pengujian Pengendalian Motor Induksi Terhadap Variasi Sudut Penyalaan}

Pengujian kendali motor induksi satu fasa menggunakan cycloconverter dengan TRIAC sebagai komponen utamanya untuk pengendali tegangan AC. Pada pengendalian tegangan AC ini diberikan sinyal pemicu atau dengan memberkan sudut penyalaan pada triac. Sudut penyalaan diberikan yaitu sebesar $0^{\circ}, 30^{\circ}, 45^{\circ}$, $60^{\circ}$ dan $90^{\circ}$ yang dikontrol dengan menggunakan arduino. Pemberian sudut penyalaan untuk melihat bagaimana motor induksi dapat beroperasi jika diberi sudut penyalaan yang berbeda. Pengujian ini diharapkan dapat menghasilkan tegangan secara bertahap sampai tegangan nominal motor induksi satu fasa. Adapun data hasil pengujian pengendalian motor induksi terhadap variasi sudut penyalaan ditunjukkan pada Tabel 2 .

Tabel 2. Hasil Pengujian Variasi Sudut Penyalaan

\begin{tabular}{|c|c|c|c|c|c|c|c|c|c|c|}
\hline \multirow{2}{*}{$\begin{array}{l}\text { Sudut Penyalann } \\
\text { (a) }\end{array}$} & \multirow{2}{*}{ Frekuensi } & \multirow{2}{*}{$\begin{array}{l}\text { Actual Frekuensi } \\
(\mathrm{Hz})\end{array}$} & \multicolumn{2}{|c|}{$\begin{array}{l}\text { Tegangan } \\
(V)\end{array}$} & \multicolumn{2}{|c|}{$\begin{array}{l}\text { Arus } \\
\text { (A) }\end{array}$} & \multicolumn{2}{|c|}{$\begin{array}{l}\text { Daya } \\
\text { (IV) }\end{array}$} & \multicolumn{2}{|c|}{$\begin{array}{c}\text { Kecepatan } \\
\text { (RPM) }\end{array}$} \\
\hline & & & $V_{\text {in }}$ & $V_{\text {out }}$ & $\mathrm{I}_{\text {in }}$ & $\mathrm{I}_{\text {eat }}$ & $\mathrm{Pa}_{\mathrm{a}}$ & $P_{\text {vat }}$ & $\mathrm{N}_{\mathrm{s}}$ & $\mathrm{N}_{\mathrm{r}}$ \\
\hline \multirow{3}{*}{$0^{\circ}$} & fil & 50 & \multirow{3}{*}{220} & 210 & 0,5 & 0,3 & 110 & 63 & 3000 & 2865 \\
\hline & fi2 & 25 & & 208,3 & 0,7 & 0,4 & 154 & 83,32 & 1500 & 1435 \\
\hline & fi 3 & 16,67 & & 207,5 & 0,9 & 0,6 & 198 & 124,5 & 1000,2 & 834,2 \\
\hline \multirow{3}{*}{$30^{\circ}$} & fil & 50 & \multirow{3}{*}{220} & 204,7 & 0,5 & 0,3 & 110 & 61,41 & 3000 & 2829 \\
\hline & fi 2 & 25 & & 203,5 & 0,6 & 0,4 & 132 & 81,4 & 1500 & 1351 \\
\hline & fi3 & 16,67 & & 202,9 & 0,7 & 0,5 & 154 & 101,45 & 1000,2 & 645,7 \\
\hline \multirow{3}{*}{$45^{\circ}$} & fill & 50 & \multirow{3}{*}{220} & 203,2 & 0,4 & 0,3 & 88 & 60,96 & 3000 & 2887 \\
\hline & fi2 & 25 & & 193 & 0,8 & 0,6 & 176 & $115 ; 8$ & 1500 & 1383 \\
\hline & fi3 & 16,67 & & 189,7 & 0,8 & 0,6 & 176 & 113,82 & 1000,2 & 690,5 \\
\hline \multirow{3}{*}{$60^{\circ}$} & fil & 50 & \multirow{3}{*}{220} & 192 & 0,6 & 0,4 & 132 & 76,8 & 3000 & 2910 \\
\hline & fi2 & 25 & & 175,1 & 0,6 & 0,5 & 132 & 87,55 & 1500 & 1421 \\
\hline & fi 3 & 16,67 & & 172,4 & 0,7 & 0,6 & 154 & 103,44 & 1000,2 & 870,6 \\
\hline \multirow{3}{*}{$90^{\circ}$} & fill & 50 & \multirow{3}{*}{220} & 146,7 & 0,4 & 0,3 & 88 & 44,01 & 3000 & 2920 \\
\hline & fi2 & 25 & & 131,6 & 0,5 & 0,4 & 110 & 52,64 & 1500 & 1477 \\
\hline & fi3 & 16,67 & & 124 & 0,6 & 0,6 & 132 & 74,4 & 1000,2 & 852,2 \\
\hline
\end{tabular}
TRIAC dengan variasi frekuensi

Dari Tabel 2 dapat dilihat dengan memvariasikan nilai sudut penyalaan maka dapat diketahui nilai tegangan, arus, daya dan kecepatan putaran motor yang dihasilkan. Terlihat bahwa tegangan yang didapat pada sudut penyalaan 0 derajat dengan frekuensi $50 \mathrm{~Hz}$ sebesar 210 Volt dan arus sebesar 0,3 Ampere dan kecepatan putaran motor sebesar 2865 RPM, diukur hingga sudut penyalaan 90 derajat dengan frekuensi $16,67 \mathrm{~Hz}$ sebesar 124 Volt dan arus sebesar 0,6 Ampere dan kecepatan putaran motor sebesar 852,2 RPM. Dari hasil data yang didapatkan dapat disimpulkan bahwa semakin besar sudut penyalaan yang diberikan akan mengakibatkan turunnya tegangan output dan arus output cukup konstan seiring perubahan sudut penyalaan sementara ketika frekuensi yang diberikan semakin kecil maka kecepatan putaran motor akan semakin menurun. Adapun grafik hubungan tegangan terhadap sudut penyalaan dapat dilihat pada Gambar 6.

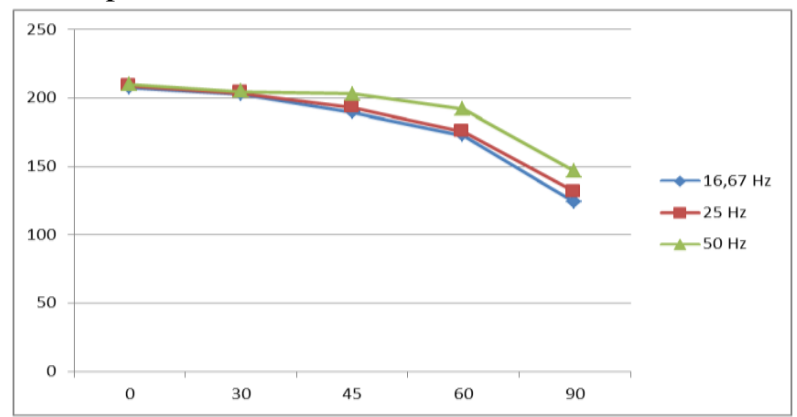

Gambar 6. Grafik Hubungan Tegangan Terhadap Sudut Penyalaan pada

Berdasarkan Gambar 6 Grafik hubungan tegangan terhadap sudut penyalaan menunjukkan bahwa semakin besar sudut penyalaan yang diberikan maka tegangan yang diberikan akan semakin berkurang.

Sebagai sampel pengujian ini, diambil data pada sudut penyalaan 90 derajat untuk mengetahui hubungan antara kecepatan terhadap frekuensi. Adapun grafik hubungan kecepatan terhadap frekuensi dapat dilihat pada Gambar 7.

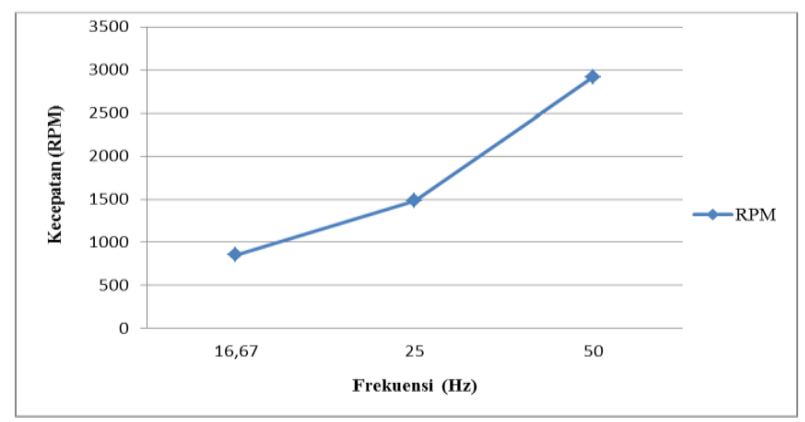

Gambar 7. Grafik Hubungan Kecepatan Terhadap Frekuensi

Berdasarkan Gambar 7 grafik hubungan kecepatan terhadap frekuensi menunjukkan bahwa semakin besar frekuensi yang diberikan maka kecepatan motor akan semakin cepat. Ketika frekuensi terendah yang diberikan sebesar $16,67 \mathrm{~Hz}$ kecepatan putaran motor yang dihasilkan sebesar 852,2 RPM. Pada saat frekuensi sebesar $25 \mathrm{~Hz}$ kecepatan putaran motor yang dihasilkan langsung naik sebesar 1477 RPM dan pada frekuensi tertinggi yang diberikan sebesar $50 \mathrm{~Hz}$ kecepatan putaran motor yang dihasilkan sebesar 2920 RPM. 
Setelah dilakukannya pengujian kecepatan terhadap frekuensi dengan perubahan sudut penyalaan sebesar 90 derajat, maka dapat dibuat grafik hubungan kecepatan terhadap tegangan yang dapat dilihat pada Gambar 8.

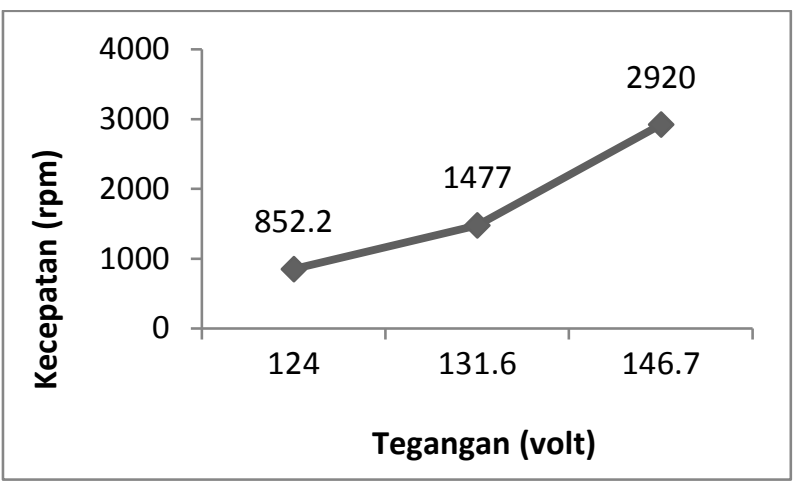

Gambar 8. Grafik Hubungan Kecepatan Terhadap Tegangan pada frekuensi $50 \mathrm{~Hz}$

Berdasarkan Gambar 8 grafik hubungan kecepatan terhadap tegangan menunjukkan bahwa untuk nilai frekuensi yang sama, semakin besar tegangan yang diberikan maka kecepatan motor akan semakin cepat. Tegangan terkecil yang terukur yaitu pada saat kecepatan putaran motor sebesar 852,2 RPM dengan tegangan 124 Volt, sedangkan tegangan yang tertinggi yaitu pada saat kecepatan putaran motor sebesar 2920 RPM dengan tegangan 146,7Volt.

Sedangkan untuk mengamati hubungan antara sudut penyalaan dengan kecepatan, dapat dilihat pada Gambar 9. Dari Gambar 9 terlihat pada frekuensi yang sama yaitu f/1 atau $50 \mathrm{~Hz}$, maka kecepatan cenderung naik dengan naiknya sudut penyalaan, kecuali dari sudut penyalaan $0^{\circ}$ ke $30^{\circ}$ mengalami penurunan tetapi setelah itu naik. Trend yang sama juga didapatkan pada frekuensi $\mathrm{f} / 2$ dan $\mathrm{f} / 3$.

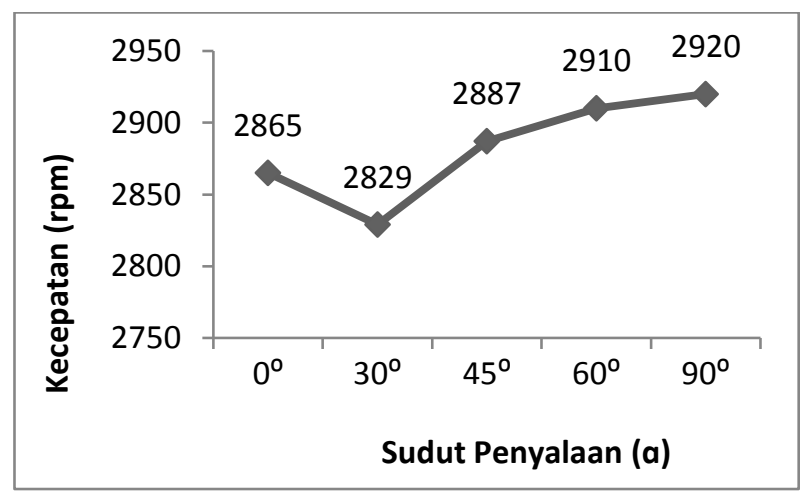

Gambar 9. Grafik hubungan sudut penyalaan terhadap kecepatan pada frekuensi $50 \mathrm{~Hz}$

Untuk pengamatan terhadap daya motor pada variasi sudut penyalaan dapat dilihat pada Gambar 10 . Untuk nilai frekuensi yang sama yaitu $50 \mathrm{~Hz}$, terlihat bahwa seiring dengan kenaikan sudut penyalaan maka daya semakin turun, kecuali pada sudut penyalaan $60^{\circ}$ mengalami peningkatan kemudian turun lagi di sudut $90^{\circ}$.

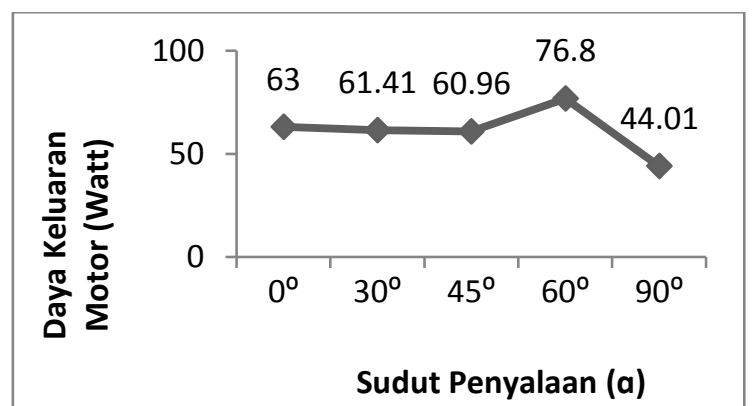

Gambar 10. Grafik hubungan sudut penyalaan terhadap daya keluaran motor pada frekuensi $50 \mathrm{~Hz}$

\section{KESIMPULAN}

1. Dari hasil pengujian didapatkan bahwa semakin besar sudut penyalaan TRIAC pada cycloconverter maka tegangan akan semakin turun dengan tegangan tertinggi sebesar $210 \mathrm{~V}$ pada frekuensi $50 \mathrm{~Hz}$ dengan sudut penyalaan $0^{\circ}$ dan terendah sebesar $124 \mathrm{~V}$ pada frekuensi $16,67 \mathrm{~Hz}$ dengan sudut penyalaan $90^{\circ}$..

2. Untuk nilai frekuensi yang sama, maka semakin besar sudut penyalaan maka kecepatan akan semakin meningkat, sedangkan daya akan semakin menurun.

\section{DAFTAR PUSTAKA}

[1] P.C. Sen, Principles of Electric Machines and Power Electronics, Edisi Kedua, John Wiley \& Sons Inc, Canada, 1997.

[2] N.Mohan, T. Undeland, W. Robbins, "Power Electronics: Converters, Applications and Design”, Edisi Kedua, John Wiley \& Sons Inc, New York, 1992.

[3] Tarmizi. 2010. Desain Sistem Kontrol Sudut Penyalaan Thyristor Komutasi Jaringan Berbasis Mikrokontroler PIC 16F877. Universitas Syiah Kuala. Banda Aceh, 2010.

[4] Karnika Sharma, dkk. 2016. Speed Control of Single Phase Induction Motor Using TRIAC \& Reversal of Direction, Vol.3, 2016.

[5] Ayebatonye Marttyns Epemu, Kingsley Okeoghene Enalume, Speed Control of a Single Phase Induction Motor Using Step-down Cycloconverter. Nigeria.2018.

[6] Arindya, Radita, Penggunaan dan Pengaturan Motor Listrik. Graha Ilmu: Yogyakarta, 2013.

[7] Sumardjati, Prih, Teknik Pemanfaatan Tenaga Listrik Jilid 3, Hlm 90. Jakarta, 2008.

[8] Djoekardi, Djuhana, Mesin-Mesin Listrik Motor Induksi. Universitas Trisakti: Jakarta, 1996.

[9] Sumanto,Drs, Motor Listrik Arus Bolak-Balik. Yogyakarta. Hlm.43. Jakarta, 1993.

[10] Zuhal, Dasar Tenaga Listrik Dan Elektronika Daya. PT Gramedia Pustaka Utama: Jakarta, 1998. 